\title{
RISK FACTORS FOR IMPAIRED BONE DENSITY IN MALE PATIENTS UNDERWENT HEMODIALYSIS DUE TO CHRONIC KIDNEY DISEASE
}

\author{
Patritius Kelik Dwi Santo Ismoyo ${ }^{1}$ dan Sugeng Yuwana ${ }^{1^{*}}$ \\ ${ }^{1}$ SMF/ Divisi Orthopaedi dan Traumatologi, Departemen Bedah, RSUP Dr. Sardjito/ \\ Fakultas Kedokteran, Kesehatan Masyarakat dan Keperawatan \\ Universitas Gadjah Mada, Yogyakarta \\ *Corresponding Author: Sugeng Yuwana, SMF/ Divisi Orthopaedi dan Traumatologi, \\ Departemen Bedah, RSUP Dr. Sardjito/Fakultas Kedokteran, Kesehatan Masyarakat dan \\ Keperawatan, Universitas Gadjah Mada Yogyakarta, Jl. Kesehatan no 1, Yogyakarta \\ E-mail: sugengyuwana@yahoo.com
}

\begin{abstract}
ABSTRAK
Latar Belakang: Penyakit ginjal kronis (PGK) sering disertai dengan gangguan metabolisme mineral yang bisa mengakibatkan penurunan kepadatan tulang seperti osteopenia dan osteoporosis.

Tujuan: Penelitian ini bertujuan untuk mengetahui faktor risiko penurunan kepadatan tulang yang dinilai dengan bone mineral density (BMD) pada penderita PGK stadium V yang menjalani hemodialisis.

Metode: Penelitian cross sectional ini dilakukan pada pasien Unit Hemodialisa RSUP Dr. Sardjito Yogyakarta selama bulan Juni 2014. Subyek harus berusia lebih dari 18 tahun dan telah menjalani hemodialisis selama minimum 6 bulan. Kepadatan tulang lumbar spine, total hip dan femoral neck dinilai dengan DEXA. Data umur dan etiologi PGK dilihat dari rekam medis. Berat dan tinggi badan diukur dengan alat yang sudah dikalibrasi. Data dianalisis dengan piranti lunak OpenEpi.

Hasil: Penelitian ini melibatkan 30 pasien laki-laki dengan rerata (SB) usia 56,8 $(13,8)$ tahun. Kepadatan tulang lumbar spine dan femoral neck berhubungan bermakna dengan durasi hemodialisis, OR (IK95\%) 31,7 (3,8-856,0), p=0,0003 dan 12,0 (1,9-111,0), p=0,005 untuk yang sudah menjalani hemodialisis lebih dari 12 bulan. Obesitas hanya bersifat protektif untuk densitas total hip, OR (IK95\%) 0,1 (0,004-0,9), p=0,03. Etiologi PGK tidak mempengaruhi kepadatan tulang.
\end{abstract}

Kesimpulan: Kepadatan tulang dipengaruhi oleh durasi hemodialisis.

Kata kunci: Penyakit ginjal kronis, hemodialisis, Bone Mineral Density, DEXA

\begin{abstract}
Background: Chronic kidney disease (CKD) is associated with impairment of mineral metabolism that, in turn, may result in the derangement of bone density, i.e. osteopenia or osteoporosis.

Purpose: The objective of this study is to assess the impairment of bone density in male patients underwent routine hemodialysis due to stage V CKD.

Methods: Subjects in this cross sectional study were male patients underwent routine hemodialysis in Hemodialysis Unit Dr. Sardjito General Hospital Yogyakarta in June 2014. Subjects were invited when they were over 18 years old and had undergone hemodialysis for at least 6 months. Bone density of lumbar spine, total hip and femoral neck were assessed using DEXA. We collected information on age and the etiology of the CKD from medical records. Body weight and height were measured using calibrated apparatus. Data were analyzed using OpenEpi.

Results: We invited 30 male patients with mean (SD) age of 56.8 (13.8) years. Bone density of lumbar spine and femoral neck were significantly associated with the duration of hemodialysis, i.e. OR ( $95 \% \mathrm{CI})$ of 31.7 (3.8-856.0), $\mathrm{p}=0.0003$ and 12.0 (1.9-111.0), $\mathrm{p}=0.005$, respectively for
\end{abstract}


those underwent hemodialysis of more than 12 months. Obesity was only protective for the bone density of the total hip, OR(95\%CI) of $0.1(0.004-0.9), \mathrm{p}=0.03$. There was no association between the etiology of the CKD and the decrease in bone density.

Conclusion: This study observed significant association between the duration of hemodialysis and bone density.

Keywords: Chronic Kidney Disease, hemodialysis, bone mineral density, DEXA

\section{PENDAHULUAN}

Prevalensi penyakit ginjal kronis (PGK) di Indonesia saat ini sekitar 0,2\% dari seluruh penduduk Indonesia. ${ }^{1}$ Meskipun prevalensinya tidak terlalu tinggi, penyakit ini menduduki tempat kedua total jumlah pembiayaan yang harus dikeluarkan oleh BPJS karena PGK, selain memerlukan hemodialisis rutin, juga mempunyai banyak komplikasi. ${ }^{2,3}$

Salah satu komplikasi PGK adalah gangguan pada metabolisme tulang, suatu kondisi yang disebut sebagai renal osteodystrophy. Di samping mengakibatkan deformitas bentuk tulang, renal osteodystrophy juga meningkatkan risiko terjadinya fraktur. Kejadian fraktur mengakibatkan semakin meningkatnya morbiditas dan mortalitas penderita PGK., ${ }^{4,5}$

Renal osteodystrophy merupakan gangguan metabolisme mineral, terutama kalsium dan fosfat, akibat PGK. Patofisiologi renal osteodystrophy relatif rumit, salah satu diantaranya melalui kegagalan konversi vitamin D menjadi vitamin D3 aktif yang pada keadaan normal berlangsung di ginjal. Rendahnya aktivitas vitamin D3 akan mengganggu mineralisasi tulang dan mengakibatkan terjadinya kerusakan mikrostruktur tulang yang akan meningkatkan risiko terjadinya fraktur lowenergy. 4

Pada penelitian sebelumnya, menunjukkan peningkatan risiko 4 kali lipat fraktur pelvis pada penderita PGK stadium $\mathrm{V}$ (end stage renal disease). Suatu keadaan yang akan sangat meningkatkan risiko mortalitas. ${ }^{3,4,6}$

Penelitian ini bertujuan untuk mengetahui faktor risiko penurunan kepadatan tulang atau osteopenia/ osteoporosis yang dinilai dengan bone mineral density (BMD) penderita PGK stadium $\mathrm{V}$ (end stage renal disease) yang menjalani hemodialisis. Penelitian ini diharapkan bisa membantu memberikan informasi untuk penyusunan pedoman manajemen risiko osteoporosis pada pasien PGK.

\section{METODOLOGI PENELITIAN}

Penelitian ini merupakan penelitian cross sectional pada penderita penyakit gagal ginjal kronik (PGK) stadium V yang rutin menjalani hemodialisis. Penelitian 
dilakukan di Unit Hemodialisa dan di Departemen Radiologi RSUP Dr. Sardjito Yogyakarta selama bulan Juni 2014. Subyek penelitian adalah pasien laki-laki yang berusia 18 tahun atau lebih yang telah menjalani hemodialisis minimal selama 6 bulan. Pada penelitian ini hanya digunakan subyek laki-laki mengingat tingginya risiko osteoporosis pada wanita pasca menopause. Memilih hanya subyek laki-laki diharapkan dapat menyederhanakan analisis selanjutnya karena tidak perlu dilakukan kendali terhadap status menopause. Subyek akan dieksklusi apabila sudah pernah mengalami fraktur, telah menerima suplementasi kalsium, kalsitonin, bifosfonat atau pun terapi hormonal. Penderita juga akan dieksklusi bila merupakan penderita karsinoma dengan metastase ke tulang.

Data demografi seperti usia dan diagnosis penyakit etiologi PGK didapatkan dari rekam medis, sedangkan data berat dan tinggi badan diukur dengan timbangan injak dan stadiometer yang telah dikalibrasi sebelumnya. Indeks Massa Tubuh (IMT) dihitung dengan membagi berat badan dalam kilogram dengan kuadrat tinggi badan dalam meter.

Bone mineral density (BMD) diukur dengan mesin DEXA GE Lunar Prodigy dan piranti lunak ENCORE 2002. Pemeriksaan DEXA dilakukan oleh seorang radiografer yang sudah tersertifikasi untuk menggunakan alat tersebut. Nilai $\mathrm{T}$ pasien pada vertebra lumbalis atau lumbal spine, colum femoris atau femoral neck dan keseluruhan pelvis atau total hip dibandingkan dengan standar nilai $\mathrm{T}$ dewasa muda normal. BMD dikategorikan sebagai osteoporosis jika nilai $\mathrm{T} \leq-2,5$, osteopenia jika nilai $\mathrm{T}$ antara $-1,0 \mathrm{~s} / \mathrm{d}-2,5$, dan normal jika nilai $\mathrm{T}>$ dari $-1,0$.

Surat kelaikan etik penelitian didapatkan dari Komisi Etik Penelitian Kedokteran dan Kesehatan Fakultas Kedokteran UGM/RS Dr. Sardjito Yogyakarta. Data dientri menggunakan MS Office Excel 2007 dan dianalisis menggunakan piranti lunak OpenEpi yang dapat diakses di www.OpenEpi.com.

\section{HASIL PENELITIAN}

Penelitian ini melibatkan 30 laki-laki dengan PGK stadium V yang rutin menjalani hemodialisis. Rerata (simpang baku, SB) usia subyek penelitian adalah 56,8 $(13,8)$ tahun. Rerata (SB) tinggi badan 164,8 $(5,3)$ $\mathrm{cm}$, berat badan 64,8 $(10,6) \mathrm{kg}$ dan BMI 23,9 $(3,6) \mathrm{kg} / \mathrm{m}^{2}$. Rerata subyek telah menjalani hemodialisis selama 14,8 $(10,9)$ bulan. Detil karakteristik umur, tinggi badan, berat badan, Body Mass Index (BMI), penyakit penyebab gagal ginjal, durasi hemodialisis dan hasil BMD dapat dilihat pada Tabel 1. 
Tabel 1. Karakteristik Subyek Penelitian

\begin{tabular}{lc}
\hline \multicolumn{1}{c}{ Karakteristik } & $\begin{array}{c}\text { Frekuensi } \\
(\boldsymbol{\%})\end{array}$ \\
\hline $\begin{array}{l}\text { Durasi hemodialisis (bulan) } \\
6-12\end{array}$ & $16(53,3)$ \\
$>12$ & $14(46,7)$ \\
Umur (tahun) & $16(53,3)$ \\
$<60$ & $14(46,7)$ \\
$\geq 60$ & \\
Indeks Massa Tubuh & \\
(kg/m ${ }^{2}$ ) & $17(56,7)$ \\
Normal atau underweight & $13(43,3)$ \\
Overweight atau obes & \\
Penyebab penyakit ginjal & \\
kronis (PGK) & \\
Glomerulonefritis & $9(30,0)$ \\
Nefropati diabetes & $11(36,7)$ \\
Uropati obstruktif & $10(33,3)$ \\
\hline
\end{tabular}

Tabel 2 menunjukkan bahwa tidak ada perbedaan signifikan hasil pemeriksaan BMD berdasarkan lokasi rangka tulang. Sedangkan Tabel 3 menunjukkan bahwa Etiologi PGK tidak berhubungan dengan risiko terjadinya osteopenia ataupun osteoporosis (Tabel 3).

Tabel 2. Gambaran Hasil Pemeriksaan bone mineral density (BMD)

\begin{tabular}{llll}
\hline Lokasi & $\begin{array}{c}\text { Normal, } \\
\mathbf{n}(\boldsymbol{\%})\end{array}$ & $\begin{array}{c}\text { Osteopenia, } \\
\mathbf{n}(\boldsymbol{\%})\end{array}$ & $\begin{array}{c}\text { Osteoporosis, } \\
\mathbf{n}(\boldsymbol{\%})\end{array}$ \\
\hline $\begin{array}{l}\text { Lumbal } \\
\text { spine }\end{array}$ & $\begin{array}{l}(66,7) \\
\text { Total }\end{array}$ & $7(23,3)$ & $3(10,0)$ \\
hip & $(66,7)$ & $7(23,3)$ & $3(10,0)$ \\
$\begin{array}{l}\text { Femoral } \\
\text { neck }\end{array}$ & $\begin{array}{l}14 \\
(46,7)\end{array}$ & $12(40,0)$ & $4(13,3)$ \\
\hline
\end{tabular}

Tabel 3. Hubungan antara etiologi penyakit ginjal kronik (PGK) dengan kejadian osteoporosis atau osteopenia

\begin{tabular}{lccccc}
\hline \multicolumn{1}{c}{ Etiologi } & Osteoporosis & Osteopenia & Normal & OR (IK95\%)* & p \\
\hline A. Lumbal spine & & & & & \\
Glomerulonefritis & 0 & 3 & 6 & $0,8(0,1-6,8)$ & 0,89 \\
Nefropati diabetik & 2 & 2 & 7 & $0,8(0,1-5,1)$ & 0,78 \\
Uropati obstruktif & 1 & 2 & 7 & 1,0 (rujukan) & \\
B. Total hip & & 2 & 6 & $0,9(0,1-6,8)$ & 0,89 \\
Glomerulonefritis & 1 & 3 & 7 & $0,8(0,1-5,1)$ & 0,78 \\
Nefropati diabetik & 1 & 2 & 7 & 1,0 (rujukan) & \\
Uropati obstruktif & 1 & 4 & 5 & & \\
C. Femoral neck & & 4 & 4 & $0,6(0,1-8,3)$ & 0,83 \\
Glomerulonefritis & 0 & 4 & 5 & 1,0 (rujukan) & 0,57 \\
Nefropati diabetik & 3 & 1 & & & \\
Uropati obstruktif & & & & & \\
\hline
\end{tabular}

* OR (odds ratio) dan uji kai kuadrat dihitung dengan menggabungkan osteoporosis dengan osteopenia, serta setiap etiologi dibandingkan terhadap uropati obstrukstif sebagai rujukan; IK95\%: interval kepercayaan 95\%

Durasi menjalani hemodialisis (dalam satuan bulan) berkorelasi negatif dengan hasil BMD lumbal spine (Spearman correlation $\mathrm{r}=-0,80 ; \mathrm{p}<0,01)$ dan femoral neck $\quad(\mathrm{r}=-0,62 ; \quad \mathrm{p}<0,01)$, namun tidak berkorelasi dengan BMD total hip ( $\mathrm{r}=-0,33$; $\mathrm{p}>0,05)$. Variabel lain yang berkorelasi bermakna dengan BMD lumbal spine dan femoral neck adalah usia, sedangkan BMI tidak berkorelasi dengan BMD. Pada Tabel 3 dapat dilihat bahwa durasi mengalami hemodialisis merupakan faktor risiko 
Artikel Penelitian

Vol 7 No. 2, Oktober 2018

ISSN 2460-8742

http://journal.unair.ac.id/ORTHO@journal-orthopaedi-and-traumatology-surabaya-media-104.html

terpenting rendahnya hasil BMD. Hubungan ini terutama penting untuk lokasi lumbar spine dan femoral neck.

\section{PEMBAHASAN}

Telah disepakati secara umum bahwa rendahnya kepadatan tulang (low BMD) merupakan faktor penting terjadinya fraktur pada osteoporosis, namun pemeriksaan BMD pada penderita penyakit gagal ginjal kronik stadium $\mathrm{V}$ rutin hemodialisis belum rutin dilakukan.

Kualitas dan kuantitas tulang pada penderita penyakit gagal ginjal kronik akan terganggu, disebabkan oleh pengaruh multifaktorial pada metabolisme tubuh seperti hiperparatiroid sekunder, defisiensi vitamin D, terapi imunosupresi sebelumnya, asidosis kronik dan lainnya sehingga terjadi osteopenia, osteoporosis, dan peningkatan risiko fraktur. ${ }^{5,7}$

Pada penelitian ini didapatkan prevalensi penurunan massa tulang (osteopenia dan osteoporosis) pada BMD lumbar spine (LS), femoral neck (FN) dan total hip (TH) adalah 33,3\%; 53,3\% dan 33,3\%. Hasil ini tidak berbeda jauh dengan penelitian yang dilakukan oleh Huang tahun 2009, yaitu penurunan massa tulang LS 46\%, FN 73\%, TH 49\%) dan Taal tahun 1999. Penelitian yang dilakukan Gabay et al. mengindikasikan terjadi pengurangan massa tulang pada renal osteodystrophy lebih menonjol pada femoral neck dibandingkan tempat lain yang diduga disebabkan oleh perbedaan struktur tulang. Tulang kortikal lebih sensitif dibandingkan tulang trabekular untuk mengalami pengurangan massa tulang pada penyakit gagal ginjal. Namun penelitian lebih lanjut perlu dilakukan apakah perbedaan ini akibat perbedaan karakteristik struktur tulang. 5,7

Penelitian ini mendapatkan bahwa faktor risiko osteoporosis tradisional seperti penambahan usia dan rendahnya BMI, hanya usia penderita yang berpengaruh signifikan terhadap terjadinya penurunan massa tulang. Taal et al. pada penelitiannya menyatakan bahwa umur berpengaruh pada tingkatan massa tulang. Pertambahan usia merupakan faktor resiko penting osteoporosis yang terjadi pada orang dewasa normal, dengan rata-rata penurunan 1-2\% massa tulang/tahun dimulai sejak usia 40 tahun, dan meningkat 2-8\% dalam 5-8 tahun setelah memasuki masa menopause. ${ }^{9}$ Beberapa penelitian menemukan tidak adanya kolerasi antara penambahan usia dengan penurunan massa tulang pada wanita, namun pada pria terdapat kolerasi, yang sesuai dengan penelitian ini dimana semua peserta penelitian adalah pria dan dengan semakin baiknya prosedur dialisis meningkatkan harapan hidup penderita PGK stadium V, sehingga penambahan usia merupakan faktor penting yang 
memperberat penurunan massa tulang. Pada populasi normal pria, osteoporosis baru dimulai tampak pada usia 75 tahun ke atas, namun pada penderita gagal ginjal proses ini diperkirakan terjadi lebih awal. Pada penelitian ini mulai terjadi penurunan massa tulang (osteopenia dan osteoporosis) mulai banyak terjadi pada dekade 50-an, dimana prevalensinya $>50 \%$ pada usia tersebut. ${ }^{6,10}$

Pada populasi normal terdapat korelasi antara berat badan atau BMI dengan level kepadatan tulang, yang mana bone formation distimulasi oleh peningkatan berat badan dan meningkatkan konversi periver jaringan adiposa menjadi hormon androgen estrogen. ${ }^{11}$ Dua penelitian menyatakan terdapat kolerasi berat badan dengan kepadatan tulang pada pasien hemodialisis. Pada penelitian kami, BMI hanya mempengaruhi BMD total hip. ${ }^{12,13}$

Lamanya durasi hemodialisis berpengaruh signifikan terhadap terjadinya penurunan massa tulang (osteopenia dan osteoporosis), terutama pada lumbar spine dan femoral neck. Semakin lama menjalani hemodialisis rutin semakin tinggi pula risiko penurunan massa tulang. Hal ini sesuai dengan penelitian sebelumnya yang dilakukan oleh Huang tahun 2009 dimana didapatkan korelasi lamanya durasi hemodialisis dengan penurunan massa tulang. ${ }^{8}$
Hubungan antara lamanya hemodialisis dengan penurunan massa tulang sebenarnya hanyalah proxy dari hubungan antara lamanya menderita PGK dengan penurunan massa tulang. PGK mengakibatkan peningkatan bone turn over sebagai akibat dari hiperparatiroidisme sekunder yang disebabkan oleh gangguan homeostasis kalsium-fosfat \& vitamin D. ${ }^{14}$

Penelitian ini masih memiliki kekurangan, diantaranya jumlah sampel yang terbatas, tidak adanya data laboratorium penunjang seperti hemoglobin, albumin, hormone paratiroid, kalsium dan fosfat.

\section{KESIMPULAN}

Pada penelitian ini didapatkan prevalensi penurunan masa tulang yang cukup tinggi pada penderita penyakit gagal ginjal kronik (PGK) stadium $\mathrm{V}$ yang rutin menjalani hemodialisis, dengan regio yang paling banyak mengalami penurunan adalah regio femoral neck. Durasi hemodialisis dan usia lanjut mempengaruhi penurunan massa tulang, sedangkan BMI dan penyakit penyebab gagal ginjal tidak mempengaruhi penurunan massa tulang.

Untuk mengantisipasi peningkatan risiko fraktur pada penderita PGK, kami menyarankan pemeriksaan BMD berkala, misalnya setiap tahun, agar dapat dilakukan tindakan pencegahan yang diperlukan, 
Artikel Penelitian

Vol 7 No. 2, Oktober 2018

ISSN 2460-8742

http://journal.unair.ac.id/ORTHO@journal-orthopaedi-and-traumatology-surabaya-media-104.html

seperti memperbaiki penatalaksanaan

gangguan metabolisme mineral, penyuluhan

risiko jatuh, dan bila perlu, penggunaan

protektor panggul.

\section{REFERENSI}

1. Kementerian Kesehatan Republik Indonesia. RISKESDAS 2013. http://labdata.litbang.depkes.go.id/ri set-badan-litbangkes/menuriskesnas/menu-riskesdas/374-rkd2013. Diakses pada 9 Maret 2017.

2. Pusat Data dan Informasi Kementerian Kesehatan Republik Indonesia (InfoDATIN), Situasi Penyakit Ginjal Kronis. 9 Maret 2017. Dapat diakses di http://emojione.com.

3. Ensrud, K. Fracture Risk in CKD. Clin J Am Soc Nephrol 2013; 8: 1282 - 3

4. West, S., Lok, C., Sophie, J. Fracture Risk Assesment in Chronic Kidney Disease, Prospective Testing Under Real World Environments (FRACTURE): a prospective study. $\mathrm{J}$ MBC Nephrology.

5. Malluche, H.H., Porter, S., Daniel, F. M.C. Differences in Bone Quality in Low and High Turnover Renal Osteodystrophy. Kidney Int 2011; 23: 525-32

6. Stevens, L.A., Viswanathan, G., dan Weiner, D.E. CKD and ESRD in the Eldery: Current Prevalence, Future Projections, and Clinical Significance. 2011. Adv Chronic Kidney Dis. 2011;17(4): 293-301.

7. Gabay, C., Ruedin, P., Moe, S.M. Osteoporosis in end-stage renal disease. Semin Nephrol 1993; 13:115-23

8. Huang, G. S., Chu, T.S., Lou, M.F. Factors Associated with Low Bone Mass in the Hemodialysis Patients a cross sectional correlation study. BMC Musculoskeletal Disorders. 2009; 10:60

9. Taal, W.M., Masud, T., Green, D. et al. Risk Factor for Reduced Bone
Density in Haemodialysis Patients. Nephrol Dial Transplant. 1999; 14:1922-28

10. Chao, S.H., Tsai, K.S., Chieng, P.U. et al. Bone Mineral Density Profile in Uremic and Renal Transplant Patients. Transplant Proc. 1994; 26: 2009 - 11

11. Dawson, H. B., Shipp, C., Sadowski, L. et al. Bone Density of the Radius, Spine and Hip in Relation to Precent of Ideal Body Weight in Postmenopausal Women. Calcif Tissue Int. 1987; 40: 310 - 4

12. Stein, M.S., Packham, D.K., Ebeling, P.R., et al. Prevalence and Risk Factor for Osteopenia in Dialysis Patients. Am J Kidney Dis. 1996; 28 : 515-22

13. Flodes, A.J., Vernon, E., Popovtzer, M.M. Reduced Speed of Sound in Tibial Bone of Hemodialysed Patients: Association with Serum PTH Level. Nephrol Dial. Transplant. 1996; 11:1318-21

14. Cunningham, J., Locatelli, F., Rodrigues, M. Secondary Hyper-parathyroidism: Pathogenesis, Disease Progression and Therapeutic Options. Clin J Am Soc Nephrol. 2011; 6: 913-21 